\title{
Soil Properties of the Quarry Areas in Suleymanpasa-Tekirdağ
}

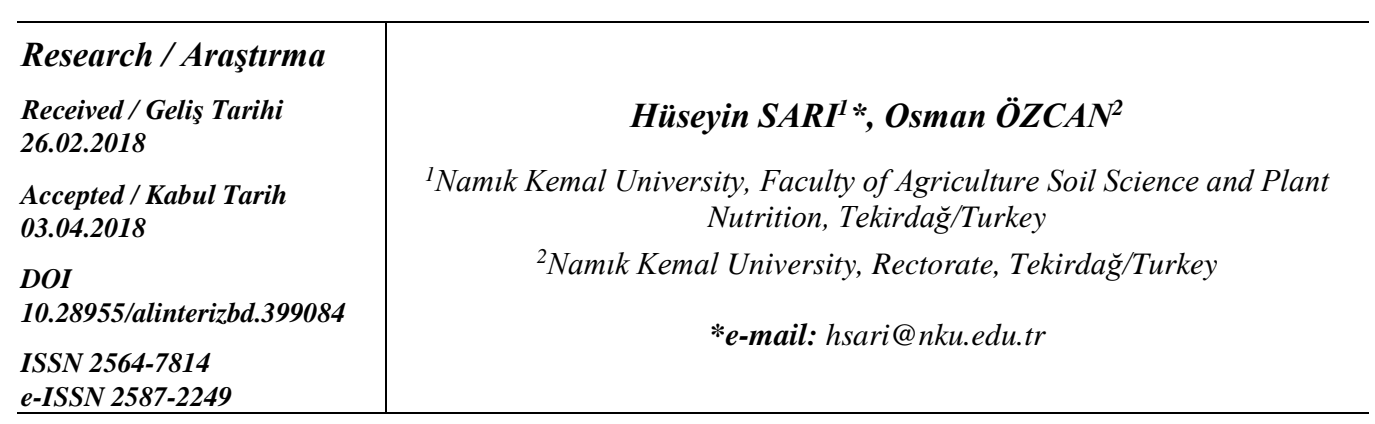

\begin{abstract}
The purpose of this study was to determine soil properties of the stone quarry area located in Suleymanpasa district of Tekirdag province of Turkey, and to assess the suitability of these areas for agriculture. The study also explored the effects of the quarries on the environment and examined the legal regulations and environmental relations. For this purpose the Great Soil Groups Map and Land Use Capability Map of the region were analyzed and identified the borders of the quarries on these maps. The borders of the quarries were superimposed on these maps using the software ArcGIS. The research results indicated that the whole area of the quarries covers class II and class III lands and the quarries operate in Grumusol and Brown Forest Soils. The size of agricultural land removed by stripping operations of the quarries was about 206 hectares and the amount of soil lost was estimated to be 4,622,000 tons based on average soil depth and bulk density.
\end{abstract}

Keywords: Soil loss, quarries, Tekirdag, soil classification,

\section{Tekirdağ İli Süleymanpaşa İlçesinde Bulunan Taş Ocakları Alanlarının Toprak Özellikleri}

Öz: Bu çalışmanın amacı Tekirdağ ili Süleymanpaşa ilçesi sınırlarında yer alan taş ocaklarının bulunduğu alanların toprak özellikleri ve tarım gerçekleştirmeye elverişli olup-olmadığının belirlenmesidir. Bölgeye ait Büyük Toprak Haritaları ve Arazi Kullanım Kabiliyeti Haritaları incelenerek, taş ocakları sınırlarının bu haritalar üzerindeki yerleri tespit edilmiştir. ArcGIS yazılımı ile taş ocakları sınırları bu haritalar ile çakıştırılmış ve sonuç olarak; taş ocakları arazilerinin tamamının II. ve III. sınıf araziler üzerinde yer aldığı ve Grumusoller ile Kahverengi Orman Toprakları üzerinde faaliyet gösterdiği belirlenmiş̧ir. Toplam 206 hektarlık alanda faaliyet gösteren taş ocakları alanından dekapaj işlemleri ile uzaklaştırılan tarım toprağı miktarı da ortalama toprak kalınlıkları ve birim hacim ağırlıkları verileriyle hesaplanmış ve 4.622.000 ton olarak bulunmuştur.

Anahtar kelimeler: Toprak kaybı, taş ocakları, Tekirdağ, toprak sınıflandırılması,

\section{Please cite this paper as follows / Lütfen aşağıdaki şekilde atıf yapınız:}

Sarı, H., \& Özcan, O., 2018. Soil Properties of the Quarry Areas in Suleymanpasa-Tekirdağ. Alınteri Journal of Agriculture Sciences, 33(1): 75-83

\section{INTRODUCTION}

Population growth and industrial developments greatly increased the need for raw materials, today. This has also led to an increase in mining activities to be able to meet this need for raw materials. Part of raw materials is supplied from stone quarries. Quarrying, a form of surface mining, is undertaken as open-pit mining.

The Regulation on Restoration of Lands Degraded by Mining Activities published in the Official Gazette dated December 14, 2007 and no. 26730 defines a quarry as a small open-pit mining enterprise that excavates industrial raw materials and materials used in buildings, roads, and other construction work and is subject to the mining law dated June 4, 1985 and no. 3213 (Anonymous, 2007).

Significant changes occur in agricultural land, vegetation transport, topography and slopes in quarrying areas. Additionally, a quarry also affects the underground water regime in the region, depending on the depth of excavation.

In this study, 12 quarries located in Suleymanpasa district of Tekirdag were analyzed in line with the field research and the data provided by official institutions (the Provincial Directorate of Environment and Urban 
Planning) (Figure 3). The quarries are mostly located around Osmanlı Mahallesi (i.e. neighborhood), Hackkoy Mahallesi, and Naip Mahallesi. The texture of soil samples taken from these regions was analyzed.

\section{MATERIALS AND METHODS}

\section{An Overview of the Study Area}

Tekirdag province located in the Thracian Region in north-west Turkey lies between north latitudes 40" 36' and 41" 31' and east longitudes 26"43' and 28" 08', in the north of the Sea of Marmara. Tekirdag is surrounded by Kirklareli and a short coastline to the Black Sea in the north, Istanbul in the east, Canakkale in the southwest, and the Sea of Marmara in the south (Anonymous, 2017).

The study area, Süleymanpaşa, which is the central district of Tekirdag province, lies between north latitudes $40^{\circ}$ $47^{\prime} 40^{\prime \prime}$ and $41^{\circ} 11^{\prime} 47^{\prime \prime}$ and east longitudes $27^{\circ} 05^{\prime} 46^{\prime \prime}$ and $27^{\circ} 42^{\prime} 19^{\prime \prime}$ in southern Tekirdag (UTM Zone $35 \mathrm{~K}$ WGS 84). Süleymanpasa occupies an area of 1131.3 square kilometers (Anonymous, 2017; Figure 1).

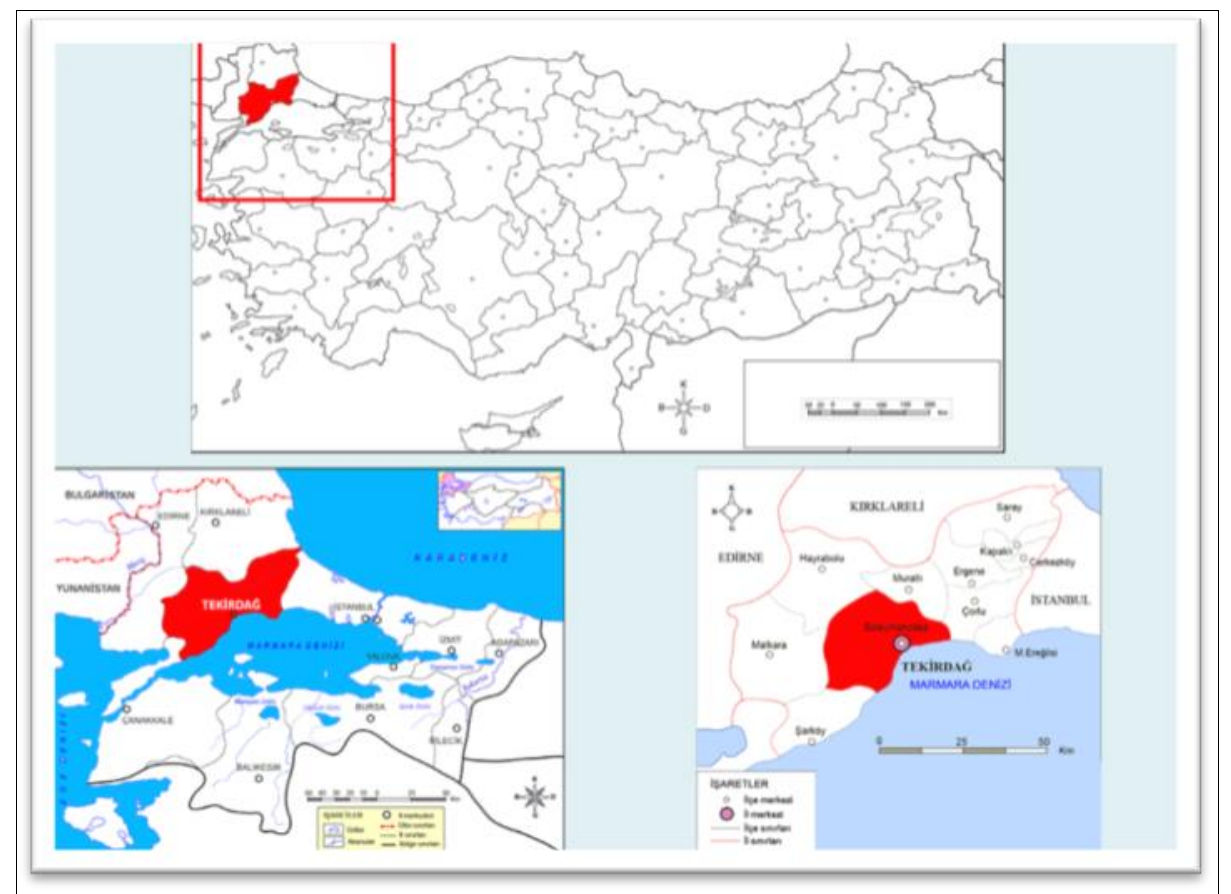

Figure 1. Study Area Map

According to the map prepared by Tekirdag Provincial Directorate of Agriculture in 2014, Suleymanpasa district has five great soil groups: alluvial soils, brown forest soils, non-calcareous brown forest soils, non-calcareous brown soils, and grumusol soils (Anonymous1993a). The locations of the quarries examined in the study area are shown on the map in Figure 3. As 23.13\% of the mapped area corresponds to settlements, the brown forest soils is the most common soil great group (Figure 2) according to the map prepared by Tekirdag Provincial Directorate of Agriculture in 2014 Süleymanpasa, has land capability classes of which $23.13 \%$ represents settlements, while $5.69 \%$ represents class I lands, $18.51 \%$ class II lands, $34.16 \%$ class III lands, $12.10 \%$ class V lands, 5.34\% class VI lands, and. 1.07\% class VII lands (Figure 4). 


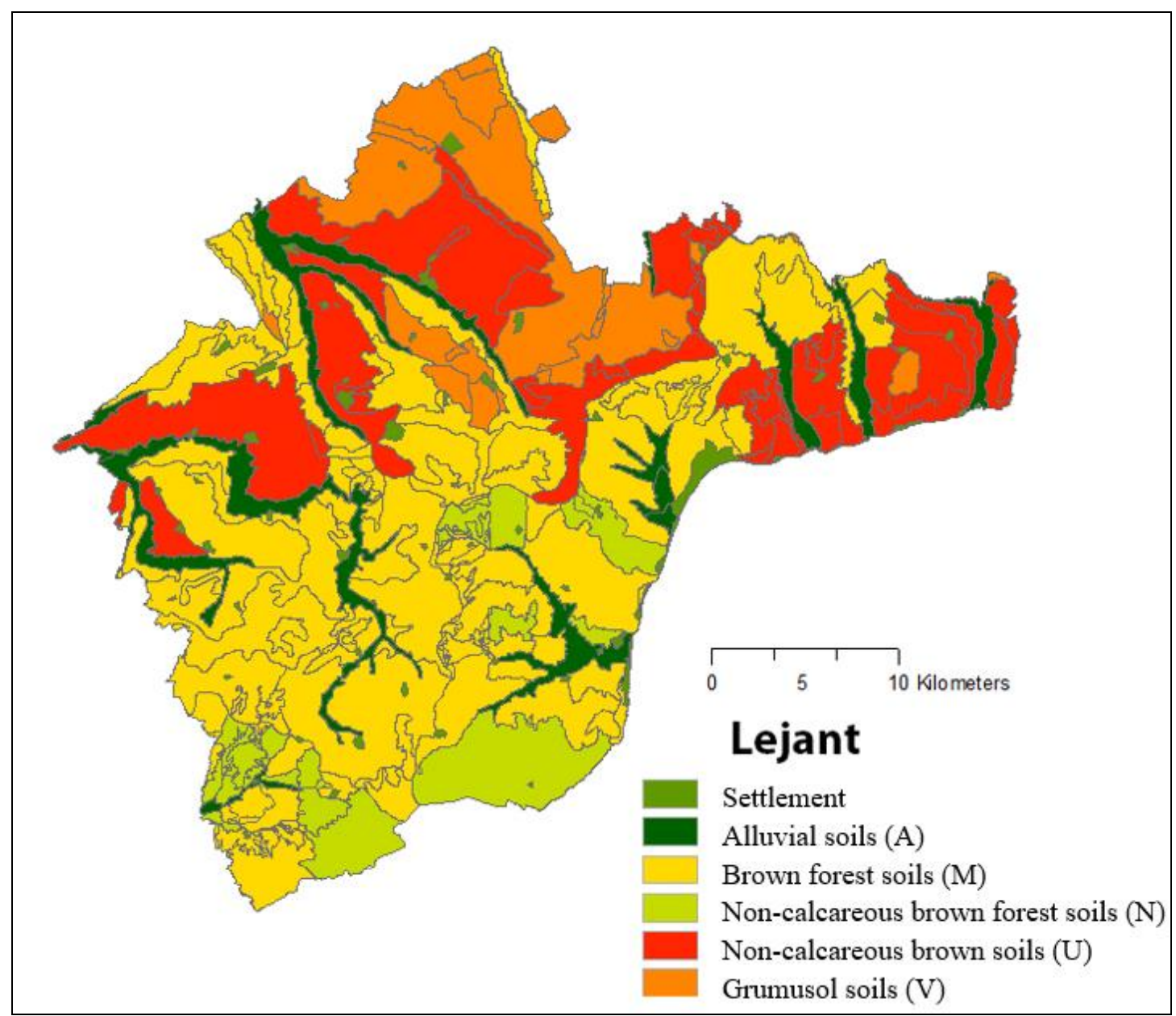

Figure Hata! Belgede belirtilen stilde metne rastlanmad1.. Great Land Groups in Süleymanpasa area.

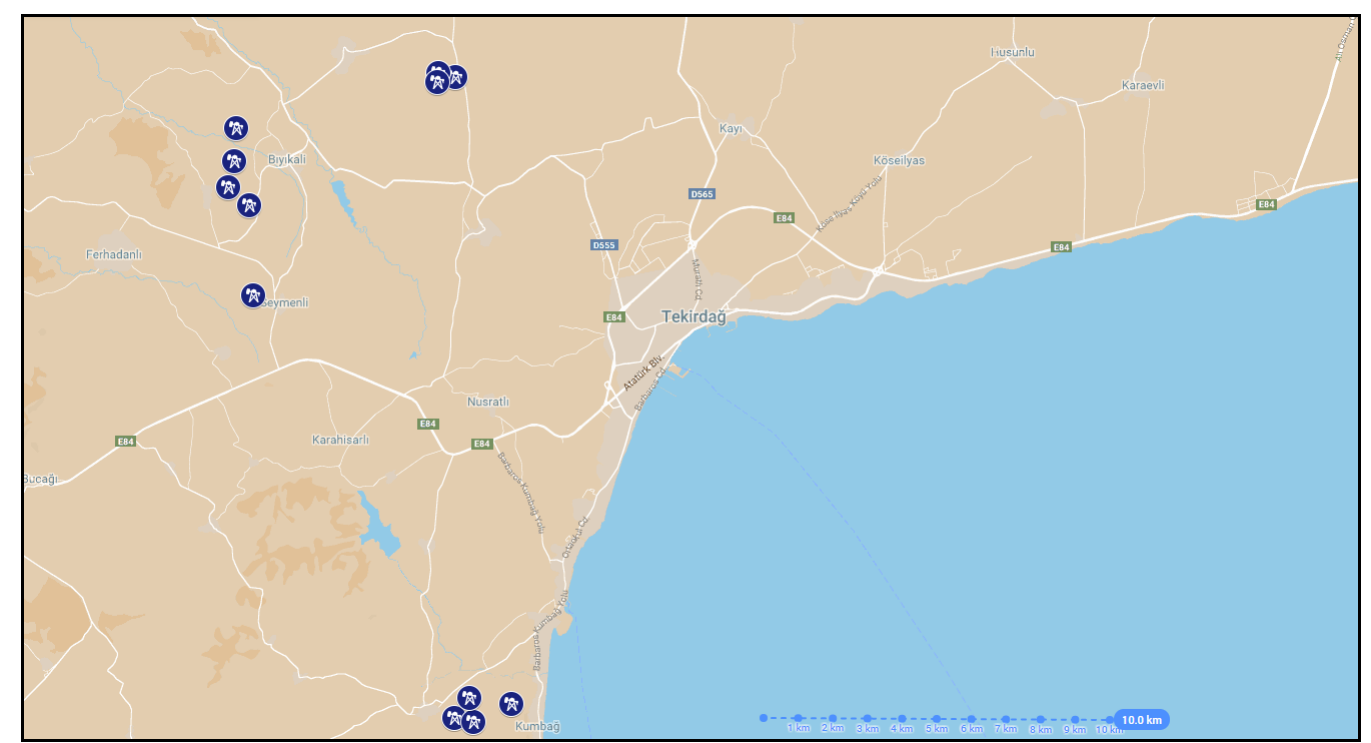

Figure 3. Studied quarries shown in the map 


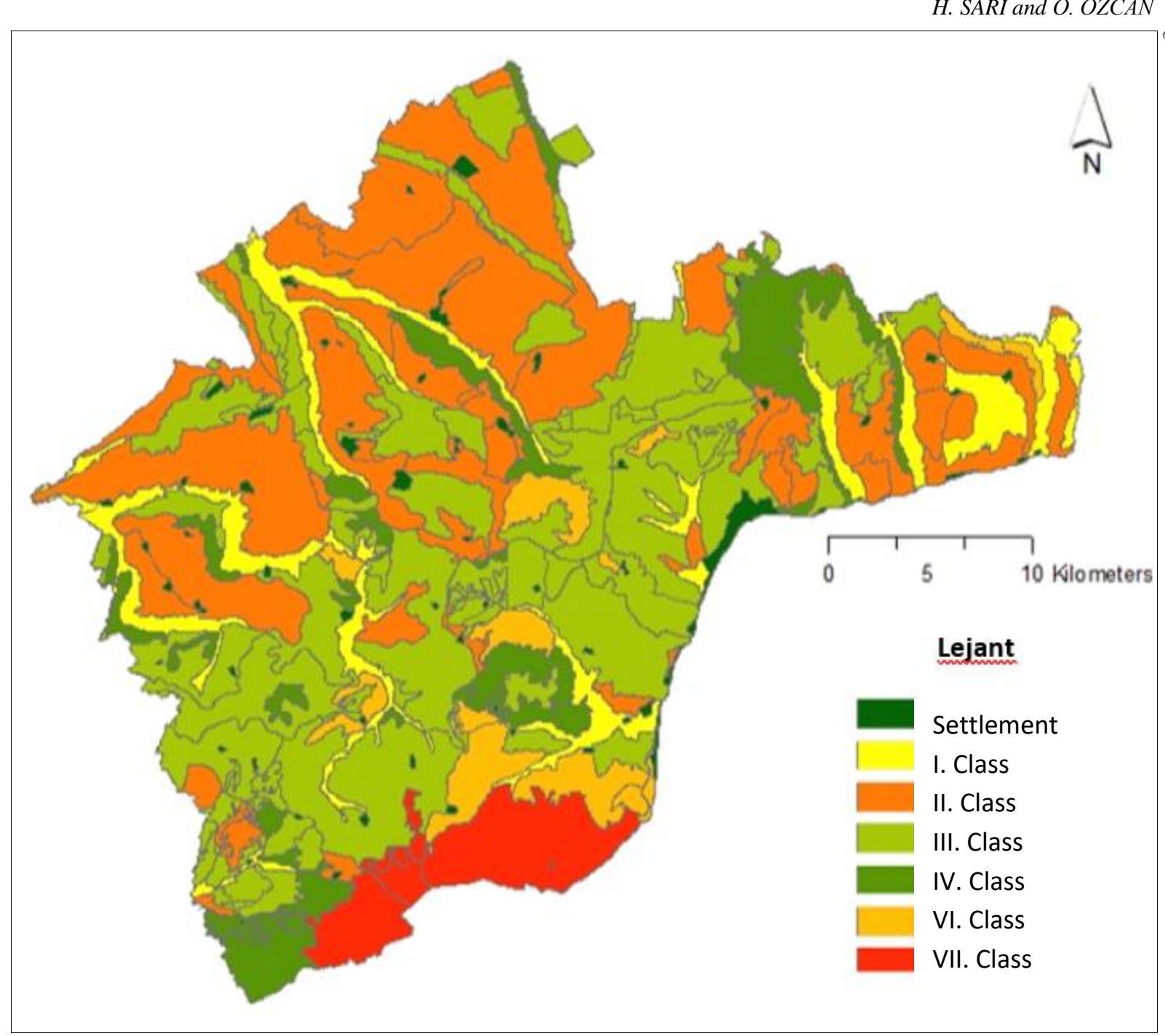

Figure 4. Land Use Capability Map of Süleymanpasa area (Anonymous 2014).

\section{Methods}

The Great Soil Groups (GSG) Map and Land Use Capability (LUC) Map of the region prepared by the Provincial Directorate of Agriculture in 2014 were obtained to identify the soil properties of the study area (Figure 2 and 4). The current borders of the quarries were superimposed on these maps through ArcGIS to determine soil groups and agricultural land classes on which the quarries operate. The texture of soil samples taken from the areas around the quarries with the depths of 30, 60 and $90 \mathrm{~cm}$ was analyzed (Figure 5).

Area and and soil depth measurements of the quarries were carried out by using Geographic Information System based softwares (GIS). Bulk densities were determined by using the table showing the average bulk density based on textures (Anonymous, 2018). The amounts of soil lost were calculated using the size of the quarry area, soil depth and soil bulk density. Among the quarries examined in this study, the lands of all quarries other than 2 , 3 , and 4 underwent weathering through the interaction of soil forming factors. In this study, as the parent material can be found at depths of meters, the soil depth in these areas was considered 2 meters (Anonymous, 1993b).

\section{RESULT AND DISCUSSION}

The quarries in Süleymanpasa district of Tekirdag are located around Naip Köy Mahallesi (Neighborhood), Hacıköy Mahallesi (Neighborhood), and Osmanlı Mahallesi (Neighborhood) (Table 1). This study examined 12 quarries in terms of soil prosperities. The coordinates of these quarries were matched with Tekirdag Great Soil Groups Map and Land Use Capability Map prepared by the Provincial Directorate of Agriculture in 2014; thus, the soil groups and agricultural land classes on which the quarries are located were determined. The soil samples taken around the quarries were analyzed for texture and the data is presented in Table 2 . The size of agricultural 
Alınteri Journal of Agriculture Sciences. 2018, 33(1): 75-83

Alınteri Zirai Bilimler Dergisi

land removed by stripping operations of the quarries operating was found to be 206 hectares and the amount of soil lost was about 4,622,000 tons (Table 3).

Table 1: Coordinates of Studied quarries

\begin{tabular}{lcc}
\hline Quarries & Latitude & Longitude \\
\hline $\mathbf{1}$ & $40^{\circ} 59^{\prime} 0.76 " \mathrm{~K}$ & $27^{\circ} 21^{\prime} 36.70 " \mathrm{D}$ \\
\hline $\mathbf{2}$ & $41^{\circ} 0^{\prime} 256 " \mathrm{~K}$ & $27^{\circ} 21^{\prime} 30.89^{\prime \prime} \mathrm{D}$ \\
\hline $\mathbf{3}$ & $41^{\circ} 0^{\prime} 42.21^{\prime \prime K}$ & $27^{\circ} 21^{\prime} 4.83^{\prime \prime} \mathrm{D}$ \\
\hline $\mathbf{4}$ & $41^{\circ} 1^{\prime} 6.32^{\prime \prime} \mathrm{K}$ & $27^{\circ} 21^{\prime} 132^{\prime \prime} \mathrm{D}$ \\
\hline $\mathbf{5}$ & $41^{\circ} 1^{\prime} 37.32^{\prime \prime} \mathrm{K}$ & $27^{\circ} 21^{\prime} 15.61^{\prime \prime} \mathrm{D}$ \\
\hline $\mathbf{6}$ & $41^{\circ} 2^{\prime} 24.10^{\prime \prime K}$ & $27^{\circ} 25^{\prime} 46.51 " \mathrm{D}$ \\
\hline $\mathbf{7}$ & $41^{\circ} 2^{\prime} 28.26 " \mathrm{~K}$ & $27^{\circ} 25^{\prime} 24.72 " \mathrm{D}$ \\
\hline $\mathbf{8}$ & $41^{\circ} 2^{\prime} 19.52^{\prime \prime} \mathrm{K}$ & $27^{\circ} 25^{\prime} 23.51^{\prime \prime} \mathrm{D}$ \\
\hline $\mathbf{9}$ & $40^{\circ} 52^{\prime} 275^{\prime \prime} \mathrm{K}$ & $27^{\circ} 25^{\prime} 44.29 " \mathrm{D}$ \\
\hline $\mathbf{1 0}$ & $40^{\circ} 52^{\prime} 40.41^{\prime \prime K}$ & $27^{\circ} 26^{\prime} 55.13 " \mathrm{D}$ \\
\hline $\mathbf{1 1}$ & $40^{\circ} 52^{\prime} 23.74 " \mathrm{~K}$ & $27^{\circ} 26^{\prime} 8.22^{\prime \prime} \mathrm{D}$ \\
\hline $\mathbf{1 2}$ & $40^{\circ} 52^{\prime} 45.81 " \mathrm{~K}$ & $27^{\circ} 26^{\prime} 2.72 " \mathrm{D}$ \\
\hline
\end{tabular}


Alınteri Journal of Agriculture Sciences. 2018, 33(1): 75-83

Alınteri Zirai Bilimler Dergisi

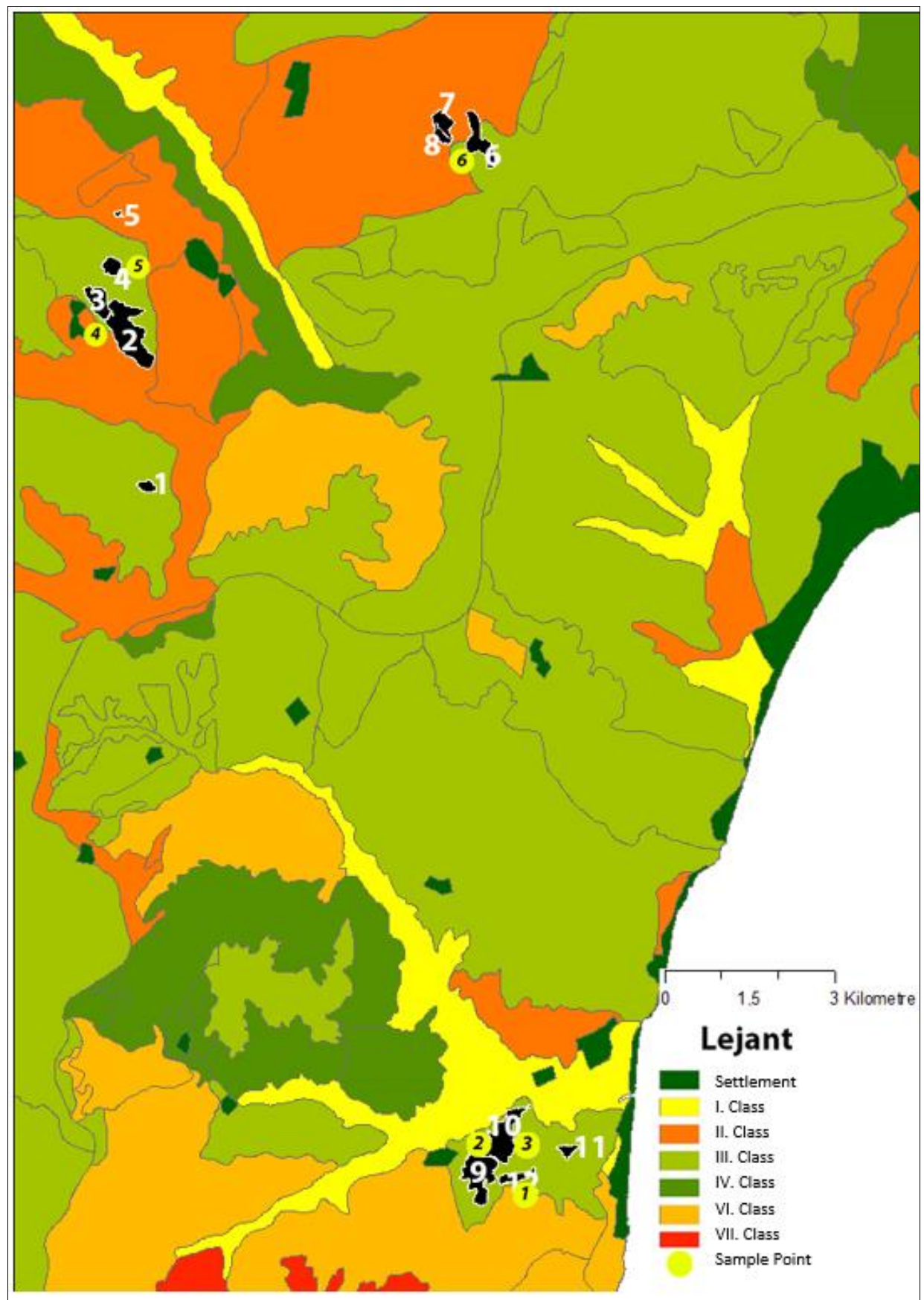

Figure 5: The Location of Soil Samples Taken from the Study Area on the Map 
Alınteri Journal of Agriculture Sciences. 2018, 33(1): 75-83

Alınteri Zirai Bilimler Dergisi

Table 2: The results of soil textural analyses

\begin{tabular}{|c|c|c|c|c|c|}
\hline \multirow{2}{*}{$\begin{array}{l}\text { Samples } \\
\text { Number }\end{array}$} & \multirow{2}{*}{ Depth (cm) } & \multicolumn{3}{|c|}{$\%$} & \multirow{2}{*}{ Texture Classification } \\
\hline & & Clay & Silt & Sand & \\
\hline \multirow{3}{*}{1} & $0-30$ & 51,57 & 37,47 & 10,96 & $\mathrm{C}$ \\
\hline & $30-60$ & 47,77 & 41,36 & 10,87 & $\mathrm{SiC}$ \\
\hline & $60-90$ & 52,14 & 41,05 & 6,81 & $\mathrm{SiC}$ \\
\hline \multirow{3}{*}{2} & $0-30$ & 51,14 & 33,35 & 15,51 & $\mathrm{C}$ \\
\hline & $30-60$ & 64,58 & 27,58 & 7,84 & $\mathrm{C}$ \\
\hline & $60-90$ & 66,27 & 25,54 & 8,19 & $\mathrm{C}$ \\
\hline \multirow{3}{*}{3} & $0-30$ & 41,15 & 49,28 & 9,57 & $\mathrm{SiC}$ \\
\hline & $30-60$ & 42,65 & 48,97 & 8,38 & $\mathrm{SiC}$ \\
\hline & $60-90$ & 33,48 & 55,13 & 11,39 & $\mathrm{SiCL}$ \\
\hline \multirow{3}{*}{4} & $0-30$ & 36,22 & 25,94 & 37,84 & CL \\
\hline & $30-60$ & 61,87 & 8,14 & 29,99 & $\mathrm{C}$ \\
\hline & $60-90$ & 56,27 & 24,15 & 19,58 & $\mathrm{C}$ \\
\hline \multirow{3}{*}{5} & $0-30$ & 52,44 & 23,68 & 23,88 & $\mathrm{C}$ \\
\hline & $30-60$ & 49,65 & 29,11 & 21,24 & $\mathrm{C}$ \\
\hline & $60-90$ & 43,44 & 36,85 & 19,71 & $\mathrm{C}$ \\
\hline \multirow{3}{*}{6} & $0-30$ & 58,65 & 18,54 & 22,81 & $\mathrm{C}$ \\
\hline & $30-60$ & 60,22 & 23,14 & 16,64 & $\mathrm{C}$ \\
\hline & $60-90$ & 65,25 & 19,98 & 14,77 & $\mathrm{C}$ \\
\hline
\end{tabular}

Table 3: The Mass of Soil Removed from the Quarry Areas in Süleymanpasa

\begin{tabular}{lccc}
\hline Quarry & Depth $(\mathbf{m})$ & Bulk Density $\left(\mathbf{g r} / \mathbf{c m}^{\mathbf{3}}\right)$ & Soil Loss (tonne) \\
\hline Sample 1 & 2,00 & 1,35 & $127.557,88$ \\
\hline Sample 2 & 1,30 & 1,35 & $926.082,28$ \\
\hline Sample 3 & 0,80 & 1,35 & $173.761,95$ \\
\hline Sample 4 & 1,50 & 1,40 & $164.092,57$ \\
\hline Sample 5 & 2,00 & 1,40 & $36.178,91$ \\
\hline Sample 6 & 2,00 & 1,25 & $571.104,63$ \\
\hline Sample 7 & 2,00 & 1,25 & $282.368,50$ \\
\hline Sample 8 & 2,00 & 1,25 & $141.817,50$ \\
\hline Sample 9 & 2,00 & 1,30 & $895.444,21$ \\
\hline Sample 10 & 2,00 & 1,30 & $918.099,81$ \\
\hline Sample 11 & 2,00 & 1,50 & $168.021,78$ \\
\hline Sample 12 & 2,00 & 1,35 & $218.205,01$ \\
\hline & & TOTAL & $\mathbf{4 . 6 2 2 . 7 3 5 , 0 2}$
\end{tabular}

When the borders of the active quarries in Süleymanpasa district were superimposed on the LUC map of the district, it showed that all of 12 quarries cover class II and class III lands. According to the LUC classification, $19.73 \%$ of the quarries (41 hectares) operates on class II lands, while $80.27 \%$ (165 hectares) operates on class III lands.

When the borders of the active quarries in Süleymanpasa district were superimposed to the GSG map of the district, it showed that of all 12 quarries are located on grumusol and brown forest soils. $60.79 \%$ of the total area covered by the quarries (125 hectares) is situated on brown forest soils and $39.21 \%$ ( 81 hectares) on grumusol soils. 
It was calculated that a total of 4,622,000 tons of soil was loss from the quarry operating areas of which $902,000{ }^{\circ}$ tons from II. Class lands and 3,720,000 tons from III. Class lands. Considering the relation of soil losses with GSG, about 1,645,000 tons of soil were lost from grumusols and 2,977,000 tons from brown forest soils.

Considering that the closeness of the quarries to settlements and their location on class II and class II lands, it seems that the quarries disregarded the needs of residents. Over 4,6 million tons of soil were removed from the region due to the operations of the quarries. If a quarry is opened on arable lands, it is of vital importance to properly excavate and store soil formed through chemical and physical processes under various conditions for many years in order to ensure that it is reusable.

Considering a number of important issues other than the volume of soil loss in the quarries, most of the quarries have environmental effects such as dust, noise, tremor, and visual pollution as they do not operate properly. Considering that the quarries are close to the settlements and there may be dense dust particles suspended in the air, it seems that there will be a possible discomfort to human health. It was observed that all roads to the mine sites are dirt (unpaved) tracks. Heavy vehicles constantly traveling from and to the quarries kick up dust from the ground and this dust can reach agricultural and residential areas in the immediate vicinity. Thus, if roads are paved with asphalt before a quarry is opened, it helps to avoid dust pollution. Another important issue is postponing making the opened quarries available although the extracted material runs up, but the contracts do not expire yet. Counting on the financial gain, companies postpone the recovery of the land until the termination of their contracts although the material runs up. Thus, the current situation should be improved through inspections and additional articles to contract provisions in order to bring solutions so that quarries that have been kept open for many years can be closed and introduced to people's use.

The deep holes dug for the quarry operations have led to a change in the watercourse in the region, the cracks and cave systems in the natural structure of the soil. Due to the effects of these quarries, the groundwater level in the region goes deeper and causes a loss of efficiency in agricultural lands.

The study area has dirt (unpaved) roads leading to the quarries. The surrounding settlements and agricultural lands are covered with dust during the removal of the materials extracted from the quarries along the dirt roads. The dust derives from both the uncovered material carried by vehicles and from the dirt roads.

\section{CONCLUSION}

In conclusion, there are great quarry reserves in Tekirdağ. Considering the areas of use, careful and detailed planning should be undertaken to avoid raw material problems in the next years. The quarries are close to the settlements, which presents various problems. Because most of the quarries do not carry out operations properly, they lead to environmental effects such as dust, noise, tremor, and visual pollution. Considering that the quarries are close to the settlements and there may be dense dust particles suspended in the air, it will probably cause damage or discomfort to human health. All roads to the mine sites are dirt (unpaved) tracks. Heavy vehicles constantly traveling from and to the quarries kick up dust from the ground and this dust can reach agricultural and settlements in the immediate vicinity. Thus, if roads are paved with asphalt before a quarry is opened, it helps to avoid dust pollution. Additionally, the surroundings of the quarries should be planted for screening purposes. When a quarry is first opened, the topsoil, which is the most productive part of the soil, should be removed and stored in suitable places and the productive soil should be prevented from being thrown away. Quarry operations should be regularly inspected and quarries close to settlements should not be allowed in order to prevent negative effects of quarries. Owners of quarrying companies and people using this area should be made aware of such problems. Regular inspection should be carried out and all necessary precautions should be taken to promote the implementation of "the regulation on the natural rehabilitation of land degraded by mining activities" so that quarrying activities can be maintained without any damage. The regulation on the natural rehabilitation of land degraded by mining activities published in the Official Gazette dated January 23, 2010 and numbered 27471 regulates the restoration of degraded natural resources and provides that agricultural lands are used in line with the opinion of the Ministry of Agriculture. Mining activities in agricultural lands are allowed in accordance with article 13 of the Law No. 5403 on Soil Preservation; however, the non-purpose use of agricultural lands is allowed by the ministry on condition that soil preservation projects are followed. The ministry can also delegate this authority to governorships. Thus, the authorizing body should strictly inspect the suitability and implementation of soil preservation projects. If these rules are followed, it will be possible to restore lost lands to those that can be reused by people. Another important issue is postponing making the opened quarries available although the extracted material runs up, but the contracts do not expire yet. Counting on the financial gain, companies postpone the recovery of the land until the termination of their contracts although the material runs up. Thus, the current situation should be improved through inspections and additional articles to contract provisions in order to bring solutions so that quarries that have been kept open for many years can be closed and introduced to people's use. 
Alınteri Journal of Agriculture Sciences. 2018, 33(1): 75-83

Alınteri Zirai Bilimler Dergisi

ACKNOWLEDGEMENTS

This work has been made from master's thesis that was supported by Namık Kemal University Scientific Research Projects Unit (BAP) as project NKUBAP.03.YL.17.087.

\section{REFERENCES}

Anonymous (1993a). Tekirdag İl Arazı Varlığı ve Arazilerin Tarımsal Kullanma Uygunluğu T. C. Başbakanlık Köy Hizmetleri Genel Müdürlüğü Etüd ve Proje Dairesi Başkanlığı. İl Rapor No: 59, Ankara.

Anonymous (1993b). Examination and Description of Soils. Soil Survey Manual, United States Department of Agriculture, $315 \mathrm{p}$, Washington,USA.

Anonymous (2007). Madencilik Faaliyetleri ile Bozulan Arazilerin Doğaya Yeniden Kazandırılması Yönetmeliği, 14 Aralık 2007 tarih ve 26730 sayılı Resmi Gazete.

Anonymous (2014). Tekirdag İl Tarım Müdürlüğü Tekirdag BTG ve AKK Haritaları.

Anonymous (2017). Tekirdag Genel Bilgiler. Tekirdag İl Kültür ve Turizm Müdürlüğü, http://www. tekirdagkulturturizm.gov.tr/TR,75726/genel-bilgiler.html

Anonymous (2018). Estimating Moist Bulk Density by Texture. Natural Resources Conservation Center United States Department of Agriculture, https://www.nrcs.usda.gov/ wps/portal/nrcs/detail/ soils/survey/office/ssr10/ tr/?cid=nrcs144p2_074844 (17.01.2018). 